JURNAL ILMIAH KOMPUTERISASI AKUNTANSI, Vol. 13, No. 1, Juli 2020, pp. 37 - 46

p-ISSN : 1979-116X (print)

e-ISSN : 2614-8870 (online)

http://journal.stekom.ac.id/index.php/kompak

\title{
AHP Method for Selecting Wood As Furniture Raw Material
}

\author{
Gatot Setiawan', Imam Husni Al Amin² \\ ${ }^{1}$ Universitas Stikubank \\ Jl. Trilomba Juang No 1 Semarang, (62-24) 8451976, e-mail: gatotsetiawan12@gmail.com \\ ${ }^{2}$ Universitas Stikubank \\ Jl. Trilomba Juang No 1 Semarang, (62-24) 8451976, e-mail: ${ }^{2}$ imam@edu.unisbank.ac.id
}

\begin{tabular}{|c|c|}
\hline ARTICLE INFO & ABSTRACT \\
\hline $\begin{array}{l}\text { Article history: } \\
\text { Received } 30 \text { Mei } 2020 \\
\text { Received in revised form } 2 \text { Juni } 2020 \\
\text { Accepted } 5 \text { Juni } 2020 \\
\text { Available online } 8 \text { Juli } 2020\end{array}$ & $\begin{array}{l}\text { Wood is an important element determining the } \\
\text { quality of a product on furniture. The lack of } \\
\text { knowledge of the furniture industry in this industry } \\
\text { causes problems to choose a decision in } \\
\text { determining the wood material to produce quality } \\
\text { and quality furniture products. Development of a } \\
\text { decision support system using the Analytichal } \\
\text { Hierarchy Process method uses wood quality } \\
\text { feasibility parameters consisting of five criteria, } \\
\text { namely Physical Physical Properties, Mechanical } \\
\text { Mechanical Properties of Wood, Wood Grade, } \\
\text { Wood Age and Wood Substance from several } \\
\text { samples. The results of this study were to produce } \\
\text { a decision from the data to determine a decision, a } \\
\text { decision support system for the purchase of wood } \\
\text { materials for a furniture industry company using } \\
\text { the Analytichal Hierarchy Process method. After } \\
\text { testing, it can be concluded that the decision } \\
\text { obtained is appropriate for use by staff and } \\
\text { superiors and is ready to be implemented. }\end{array}$ \\
\hline
\end{tabular}

Keywords: Decision Support System, Analytichal Hierarchy Process, Wood, Furniture

\section{Introduction}

Technology has created needs in the fields of business, social and education. Especially in terms of information technology as a support to get the job done quickly. In a company in the field of selling goods can not be separated from the product production process. Products that will be asked to meet qualifications in accordance with standards set by a company. Such as the quality of materials that must meet production standards, to the costs that are calculated to get the production of raw materials at an ideal price. Raw materials are materials that form the parts to be produced, which are obtained through purchases from local, overseas, or self-processing[1]. The selection of the right raw materials affects the costs of income and expenditure. Less spending on purchasing raw materials for production will increase production profits.

In furniture production, the main raw material that is very important is wood. Wood itself has many types, and different qualities. Of the many characters of wood, not all wood can be used as raw material for production in the furniture industry. At present wood which is the main raw material for furniture is teak.

Teak wood used as raw material for production has a age of 5 years. Older wood has better quality and higher selling value. The size of the diameter of the wood also determines the price of the wood. Teak wood used as raw material for furniture has an average diameter of $14-30 \mathrm{~cm}$. the length of the wood used is different, the more straight and long, the more expensive the selling price. In the purchase of wood in Received Mei 30, 2020; Revised Juli 5, 2020; Accepted Juli 8, 2020 
Sumber Jati Muria in the number of 20 feet container units, the specified price cannot be determined by the seller based on the contents (m3). The seller provides a price based on the "appropriateness" of the goods offered. Decision making is taken by comparing the price offered by the seller with the contents / cubication in one container. There are several wood criteria that are determined based on diameter. These criteria include, A0 $=0-14 \mathrm{~cm}, A 1=15-19 \mathrm{~cm}, \mathrm{~A} 2=20-30 \mathrm{~cm}$. of the three categories have different prices. Under these conditions, every transaction to be made can be calculated from the profit from the purchase of raw materials.

Decision Support System (DDS) is a computer-based information system that produces a variety of alternative decisions to help provide decisions in dealing with existing problems both structured or not based on data and models[2]. There are several methods that can be used to build a Decision Support System, one of which is the Analytichal Hierarchy Process (AHP). The difference in the number of contents and the price of each container starts from $25 \mathrm{~m} 3$ which is worth 55 million to $25 \mathrm{~m} 3$ at a price of 65 million. The selection can be influenced by qualitative factors that are difficult to quantify. These factors can be described by the Analytichal Hierarchy Process (AHP) method by describing complex multi-factor and multi-criteria problems into a hierarchy[3].

the AHP (Analytical Hierarchy Process) method is a process of comparing criteria into alternatives, the greater the value produced, the more important it is. The development of decision support system software (DSS) using the AHP method uses wood quality feasibility parameters consisting of five criteria, namely the criteria for the physical properties of wood, mechanical properties of wood, wood grade, age of wood and substances contained in wood, the next step is to analyze the problem engineering knowledge and testing.

\section{Research Methods}

AHP is a flexible model that provides an opportunity for individuals or groups to develop ideas and define problems by making their respective assumptions and getting the desired solution from them.[4] AHP includes and considers personal values logically. This process depends on imagination, experience and knowledge to arrange the hierarchy of a problem on logic. The existing consideration is actually an interconnected state, this is because humans generally have different feelings about the same situation. But those feelings can change between one human and another by discussing and interacting with experienced people. The result is usually a compromise of many views involving major changes in the attitudes of each human being. In fact when we make decisions, personal preference and persuasion play a role more than clear and straightforward logic. AHP has three basic principles that must be carried out, namely:

2.1. The principle of compiling a hierarchy

Humans have the ability to perceive objects and ideas fatherly. Identify it, and communicate what has been observed. In order to obtain detailed knowledge, what we think about is the state of reality that is complex into parts that begin with a general goal, followed by sub-objectives, criteria and possible alternatives at the lowest criterion stage being the basic elements.

2.2. The principle sets priorities

Humans also have the ability to perceive the relationship between things that are observed, compare a pair of objects or similar things based on certain criteria and differentiate the two members of the pair by contributing to the preferences of one compared to the other. Then synthesize existing assessments through imagination or in terms of using AHP through new logical processes and obtain a better understanding of the whole system. To fill in the comparison values by using a comparative scale in pairs as in table 1.

Table 1. Comparison of intensity of interests and partners

\begin{tabular}{|c|c|c|}
\hline $\begin{array}{c}\text { intensity of } \\
\text { interests }\end{array}$ & Partner & Information \\
\hline 1 & $1 / 1$ & Both elements are equally important \\
\hline 3 & $1 / 3$ & One element is more important than the other elements \\
\hline 5 & $1 / 5$ & $\begin{array}{c}\text { One element is more important than the other elements } \\
\text { elements }\end{array}$ \\
\hline 7 & $1 / 7$ & $\begin{array}{c}\text { One element is clearly more important than the other } \\
\text { elements }\end{array}$ \\
\hline 9 & $1 / 9$ & One absolute element is more important than the other \\
\hline $2,4,6,8$ & $1 / 2.1 / 4,1 / 6,1 / 8$ & The values between the two considerations are close \\
\hline
\end{tabular}

JURNAL ILMIAH KOMPUTERISASI AKUNTANSI Vol. 13, No. 1, Juli 2020 : 37 - 46 
2.2 The principle of logical consistency

together

Humans have the ability to establish relations between objects or between thoughts so that they are coherent, that is to say, the objects or thoughts are well connected and their connections show consistency. In this principle, AHP both qualitative and quantitative aspects to express conclusions and preferences in a concise and concise manner. In this process to make healthy decisions in complex situations, where priority setting and balancing are treated. For this reason, a controller is needed in assigning values so that the decision-making process is more consistent. Consistency Ratio requires a controller value called a random index. Random index values (IR) can be seen as in table 2 below.

The AHP approach was developed departing from measurement theory related to quantitative decision criteria in decisions containing conflictual resolution. Therefore the principle of this approach seeks to accommodate the cognitive, experience and subjective knowledge aspects of decision makers as the basic data that determine the decision making process. The principle of using the AHP method starts with composing complex decision problems and then classifies the subject matter into an element in a particular hierarchy. At the same hirarli stage the paired matrix elements are compared (pairwase comparison) by including consideration of qualitative and quantitative factors.[4]

Table 2. Table matrix size and random index

\begin{tabular}{|c|c|}
\hline MATRIX SIZE & INDEX RANDOM \\
\hline 1,2 & 0,00 \\
\hline 3 & 0,58 \\
\hline 4 & 0,90 \\
\hline 5 & 1,12 \\
\hline 6 & 1,24 \\
\hline 7 & 1,32 \\
\hline 8 & 1,41 \\
\hline 9 & 1,45 \\
\hline 10 & 1,48 \\
\hline 11 & 1,51 \\
\hline 12 & 1,48 \\
\hline 13 & 1,56 \\
\hline 14 & 1,57 \\
\hline 15 & 1,59 \\
\hline
\end{tabular}




\section{Results and Discussion}

3.1. Hierarchical Structure of DSS Purchasing Timber Raw Materials.

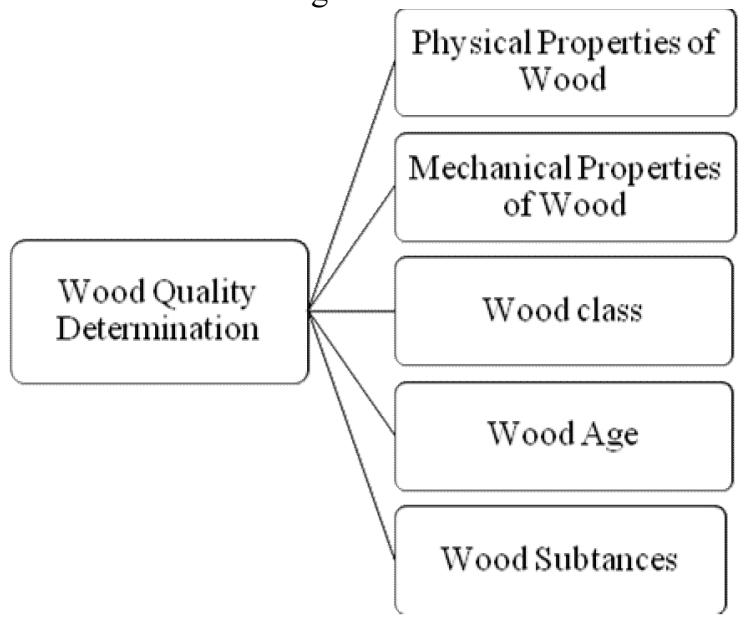

Figure 1. DSS Hierarchy Structure wood material selection selection.

3.2. AHP Calculation Hierarchy Structure.

AHP functional hierarchy with its main input is human perception. A complex and unstructured problem can be solved by each group using hierarchy. Then the groups will be organized into a hierarchical form. AHP is generally used with the aim of setting priorities from various alternative choices available and the choices are complex or multi-criteria.[5]

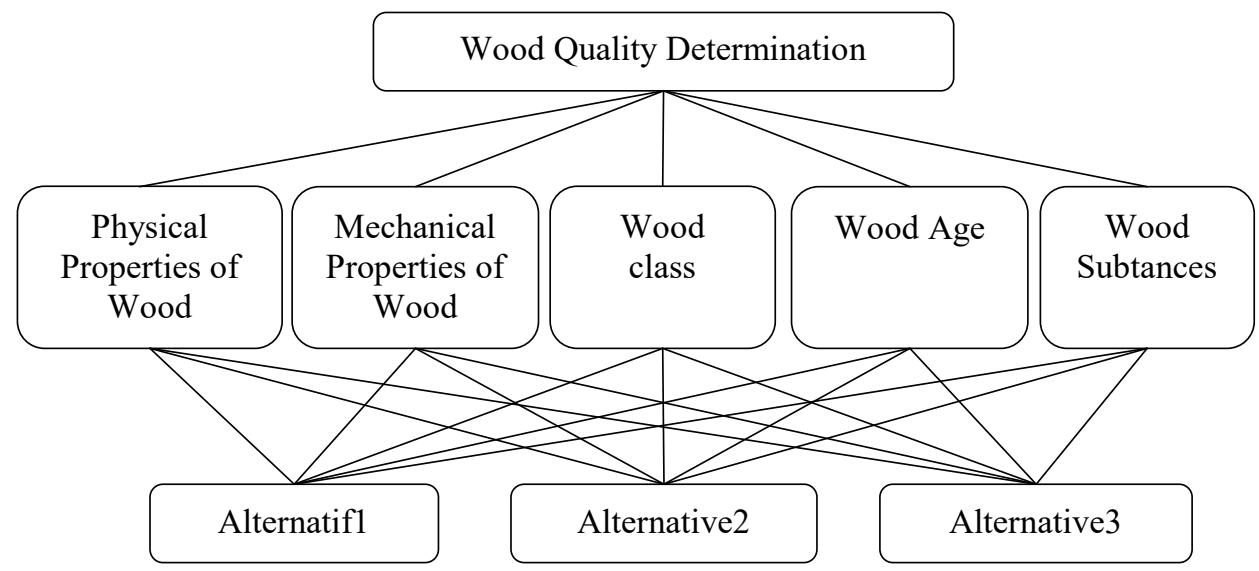

Figure 2. AHP Calculation Hierarchy Structure.

3.3. Criteria Matrix Value.

Arranging the criteria in a paired matrix illustrates the relative contribution or influence of each element to each criterion with other criteria. Comparison of criteria based on discussions and opinions with the relevant resource persons, namely the giver of wood by assessing the importance of a criterion compared to other criteria. In a way as shown in table 3.

Table 3. Table of pairwise comparison matrix values.

\begin{tabular}{|c|c|c|c|c|c|}
\hline Criteria & SFK & SMK & KK & UK & ZK \\
\hline SFK & 1 & 3 & $1 / 3$ & 4 & 2 \\
\hline SMK & $1 / 3$ & 1 & $1 / 2$ & $1 / 2$ & $1 / 2$ \\
\hline KK & 3 & 2 & 1 & 2 & 3 \\
\hline UK & $1 / 4$ & 2 & $1 / 2$ & 1 & 1 \\
\hline ZK & $1 / 2$ & 2 & $1 / 3$ & 1 & 1 \\
\hline
\end{tabular}

3.4. Simplification of Pairwise Comparison Matrix.

JURNAL ILMIAH KOMPUTERISASI AKUNTANSI Vol. 13, No. 1, Juli $2020: 37$ - 46 
After the pairwise comparison matrix is assessed, the next step is to simplify $(1 / 2=0.500,1 / 3=$ $0.333,1 / 4=0.250$ ) and the addition of values per column. As shown in table 4 below:

Table 4. Simplification table for pairwise comparison matrices.

\begin{tabular}{|c|c|c|c|c|c|}
\hline Criteria & SFK & SMK & KK & UK & ZK \\
\hline SFK & 1.000 & 3.000 & 0.333 & 4.000 & 2.000 \\
\hline SMK & 0.333 & 1.000 & 0.500 & 0.500 & 0.500 \\
\hline KK & 3.000 & 2.000 & 1.000 & 2.000 & 3.000 \\
\hline UK & 0.250 & 2.000 & 0.500 & 1.000 & 1.000 \\
\hline ZK & 0.500 & 2.000 & 0.333 & 1.000 & 1.000 \\
\hline total & 5.083 & 10.00 & 2.666 & 8.500 & 7.500 \\
\hline
\end{tabular}

3.5. Value Normalization.

After completing the process of adding up the matrix values, the normalization process is carried out by completing a number of calculation steps. The following are the values normalization steps:

Table 5. Table dividing criteria values by the number of values per column.

\begin{tabular}{|c|c|c|c|c|c|}
\hline Kriteria & SFK & SMK & KK & UK & ZK \\
\hline SFK & 1.000 & 3.000 & 0.333 & 4.000 & 2.000 \\
\hline SMK & 0.333 & 1.000 & 0.500 & 0.500 & 0.500 \\
\hline KK & 3.000 & 2.000 & 1.000 & 2.000 & 3.000 \\
\hline UK & 0.250 & 2.000 & 0.500 & 1.000 & 1.000 \\
\hline ZK & 0.500 & 2.000 & 0.333 & 1.000 & 1.000 \\
\hline jumlah & 5.086 & 10.00 & 2.666 & 8.500 & 7.500 \\
\hline
\end{tabular}

Information :

The values in table 5. above are obtained from dividing the value of the criteria by the results of the number of columns (Criteria value / column) in table 5. the division is considered correct if the value of the division per column added up will be worth (1). The following is the calculation:

- 2nd column :

$(1 / 5,08=0,1966)+(0,33 / 5,08=0,0655)+(3 / 5,08=0,5904)+(0,25 / 5,08=0,0492)+(0,5 / 5,08=0,098$ 3) $=1$

- 3rd column :

$(3 / 10=0,3000)+(1 / 10=0,1000)+(2 / 10=0,2000)+(2 / 10=0,2000)+(2 / 10=0,2000)=1$

- 4th column:

$(0,33 / 2,66=0,1249)+(0,5 / 2,66=0,1875)+(1 / 2,66=0,3750)+(0,5 / 2,66=0,1875)+(0,33 / 2,66=0,12$ $50)=1$

- 5th column: $(4 / 8,5=0,4706)+(0,50 / 8,5=0,0588)+(2 / 8,5=0,2353)+(1 / 8,5=0,1176)+(1 / 8,5=0,1176)=1$

- 6th column: $(2 / 7,5=0,2667)+(0.50 / 7,5=0,0667)+(3 / 7,5=0,4000)+(1 / 7,5=0,1333)+(1 / 7,5=0,1333)=1$

3.6. Determine Criteria Weight.

Determination of the value of criteria weights is done by adding up the results of the pairwise comparison matrix distribution in rows ( $\Sigma$ lines). Then the results of the sum of the rows divided by the number of criteria $(\Sigma$ line $/ n$ ) in the case there are 5 criteria to get the value of priority criteria weights, as shown in table 6. 
JURNAL ILMIAH KOMPUTERISASI AKUNTANSI p-ISSN : 1979-116X e-ISSN : 2614-8870 •

Table 6. Summing and dividing rows to get the priority priority weights ( $\Sigma$ lines $/ \mathrm{n}$ ).

Infromation :

\begin{tabular}{|c|c|c|c|c|c|}
\hline Criteria & SFK & SMK & KK & UK & ZK \\
\hline SFK & 0,1966 & 0,3000 & 0,1249 & 0,4706 & 0,2667 \\
\hline SMK & 0,0655 & 0,1000 & 0,1875 & 0,0588 & 0,0667 \\
\hline KK & 0,5904 & 0,2000 & 0,3750 & 0,2353 & 0,4000 \\
\hline UK & 0,0492 & 0,2000 & 0,1875 & 0,1176 & 0,1333 \\
\hline ZK & 0,0983 & 0,2000 & 0,1250 & 0,1176 & 0,1333 \\
\hline Total & 1 & 1 & 1 & 1 & 1 \\
\hline
\end{tabular}

- 2nd row : $0,1966+0,3000+0,1249+0,4706+0,2667 / 5=\mathbf{0 , 2 7 1 8}$ (the total priority value of the criteria for Physical Physical Properties).

- 3rd row : $0,0655+0,1000+0,1875+0,0588+0,0667 / 5=\mathbf{0 , 0 9 5 7}$ (the total priority value of the criteria for Wood Mechanical Properties).

- 4th row : $0,5904+0,2000+0,3750+0,2353+0,4000 / 5=\mathbf{0 , 3 6 0 1}$ (the total value of priority priority criteria for Wood Class).

- 5th row : $0,0492+0,2000+0,1875+0,1176+0,1333 / 5=\mathbf{0 , 1 3 7 5}$ (the value of the total priority weight of the Wood Age criteria).

- 6th row : $0,0983+0,2000+0,1250+0,1176+0,1333 / 5=\mathbf{0 , 1 3 4 9}$ (the value of the total priority weight of the Wood Material criteria).

For the results of Adding and dividing rows to get the priority priority weights ( $\Sigma$ lines / n) can be seen in table 7 .

Table 7. Table of priority criteria weight values.

\begin{tabular}{|l|r|}
\hline \multicolumn{1}{|c|}{ Criteria } & Weight Vector \\
\hline Physical Properties of Wood & 0,2718 \\
\hline Mechanical Properties of Wood & 0,0957 \\
\hline Wood class & 0,3601 \\
\hline Wood Age & 0,1375 \\
\hline Wood Substances & 0,1349 \\
\hline
\end{tabular}

3.7. Check Consistency Criteria.

To obtain the consistency of the comparison matrix, multiplication of all contents in column matrix A is compared with the priority weight of criteria A, and so on until the contents in the last column and the priority weight of the last criteria. Then the multiplication results are summed and then divided again by the priority priority weight values, as shown in table 8 .

Table 8. Table of matrix consistency values.

\begin{tabular}{|c|c|c|c|c|c|c|}
\hline Criteria & SFK & SMK & KK & UK & ZK & CM \\
\hline SFK & 0,19 & 0,30 & 0,12 & 0,47 & 0,26 & 5,51 \\
\hline SMK & 0,06 & 0,10 & 0,18 & 0,05 & 0,06 & 5,25 \\
\hline KK & 0,59 & 0,20 & 0,37 & 0,23 & 0,40 & 5,68 \\
\hline UK & 0,04 & 0,20 & 0,18 & 0,11 & 0,13 & 5,17 \\
\hline ZK & 0,09 & 0,20 & 0,12 & 0,11 & 0,13 & 5,33 \\
\hline
\end{tabular}

Below this is the calculation of the value of the Consistency Measure for each criterion :

- Consistency Measure Criteria Physical Properties of Wood(SFK).
$\left[\begin{array}{llll}1,00 & 3,00 & 0,33 & 4,00\end{array}\right.$
2,007
$[0,2718]$
$0,33 \quad 1,00 \quad 0,50 \quad 0,50 \quad 0,50$
$3,00 \quad 2,00 \quad 1,00 \quad 2,00$
0,0957
$\left[\begin{array}{l}0,2718 \\ 0,2871\end{array}\right]$

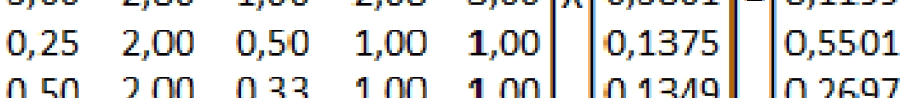
$0,3601=0,1199$
$0,2718+0,2871+0,1199+0,5501+0,2697$
0,2718 
- Consistency Measure Criteria Mechanical Properties of Wood(SMK).

$\left[\begin{array}{lllll}1,00 & 3,00 & 0,33 & 4,00 & 2,00 \\ 0,33 & 1,00 & 0,50 & 0,50 & 0,50 \\ 3,00 & 2,00 & 1,00 & 2,00 & 3,00 \\ 0,25 & 2,00 & 0,50 & 1,00 & 1,00 \\ 0,50 & 2,00 & 0,33 & 1,00 & 1,00\end{array}\right] \times\left[\begin{array}{l}0,2718 \\ 0,0957 \\ 0,3601 \\ 0,1375 \\ 0,1349\end{array}\right]=\left[\begin{array}{l}0,0906 \\ 0,0957 \\ 0,1801 \\ 0,0688 \\ 0,0674\end{array}\right]$

$0,0906+0,0957+0,1801+0,0688+0,0674$

$$
0,0957
$$

- Consistency Measure Criteria Wood Class(KK).

$\left[\begin{array}{lllll}1,00 & 3,00 & 0,33 & 4,00 & 2,00 \\ 0,33 & 1,00 & 0,50 & 0,50 & 0,50 \\ 3,00 & 2,00 & 1,00 & 2,00 & 3,00 \\ 0,25 & 2,00 & 0,50 & 1,00 & 1,00 \\ 0,50 & 2,00 & 0,33 & 1,00 & 1,00\end{array}\right] \times\left[\begin{array}{l}0,2718 \\ 0,0957 \\ 0,3601 \\ 0,1375 \\ 0,1349\end{array}\right]=\left[\begin{array}{l}0,8161 \\ 0,1914 \\ 0,3601 \\ 0,2751 \\ 0,4046\end{array}\right]$

$0,8161+0,1914+0,3601+0,2751+0,4046$

$$
0,3601
$$

- Consistency Measure Criteria Wood Age(UK).

$$
\begin{aligned}
& {\left[\begin{array}{ccccc}
1,00 & 3,00 & 0,33 & 4,00 & 2,00 \\
0,33 & 1,00 & 0,50 & 0,50 & 0,50 \\
3,00 & 2,00 & 1,00 & 2,00 & 3,00 \\
0,25 & 2,00 & 0,50 & 1,00 & 1,00 \\
0,50 & 2,00 & 0,33 & 1,00 & 1,00
\end{array}\right] \times\left[\begin{array}{l}
0,2718 \\
0,0957 \\
0,3601 \\
0,1375 \\
0,1349
\end{array}\right]=\left[\begin{array}{l}
0,0679 \\
0,1914 \\
0,1801 \\
0,1375 \\
0,1349
\end{array}\right]} \\
& \frac{0,0679+0,1914+0,1801+0,1375+0,1349}{0,1375}=C R=5,1757
\end{aligned}
$$

- Consistency Measure Criteria Wood Subtances(ZK).

$$
\begin{aligned}
& {\left[\begin{array}{lllll}
1,00 & 3,00 & 0,33 & 4,00 & 2,00 \\
0,33 & 1,00 & 0,50 & 0,50 & 0,50 \\
3,00 & 2,00 & 1,00 & 2,00 & 3,00 \\
0,25 & 2,00 & 0,50 & 1,00 & 1,00 \\
0,50 & 2,00 & 0,33 & 1,00 & 1,00
\end{array}\right] \times\left[\begin{array}{l}
0,2718 \\
0,0957 \\
0,3601 \\
0,1375 \\
0,1349
\end{array}\right]} \\
& \frac{0,1359+0,1914+0,1200+0,1375+0,1349}{0,1349}=C R=\mathbf{5 , 3 3 6 9}
\end{aligned}
$$

3.8. Lamda Value.

The next step after obtaining a matrix consistency value is to find the maximum lamda value.

The method is to divide the number of each row matrix consistency value by the number of criteria that exist, as shown in table 9.

Table 9. Lamda Value.

\begin{tabular}{|l|r|}
\hline \multicolumn{1}{|c|}{ Criteria } & \multicolumn{1}{c|}{ Lamda } \\
\hline Physical Properties of Wood & 1,1030 \\
\hline Mechanical Properties of Wood & 1,0502 \\
\hline Wood class & 1,1369 \\
\hline Wood Age & 1,0351 \\
\hline Wood Substances & 1,0674 \\
\hline Lamda Value MAX & 5,3926 \\
\hline
\end{tabular}

3.9. Ratio Index Valeu.

Ratio Index table based on the matrix order, which uses criteria with a number of 5 criteria, then the value of $\mathrm{RI}=1.12$ is used.

Table 10. Ratio index value (RI). 


\begin{tabular}{|l|c|c|c|c|c|l|}
\hline N & 1 & 2 & 3 & 4 & 5 & $\ldots$ \\
\hline RI. & 0 & 0 & 0,58 & 0,9 & $\underline{\mathbf{1 , 1 2}}$ & $\ldots$ \\
\hline
\end{tabular}

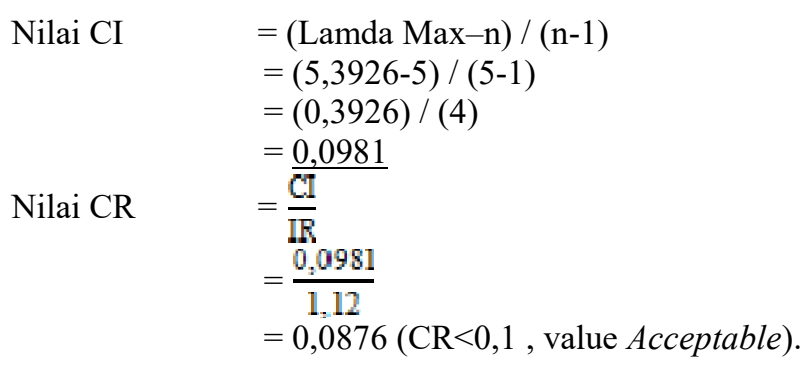

The AHP method of inconsistency in each matrix that replaces the inconsistency of the hierarchy is no longer a challenge. Hierarchical inconsistencies are more important than hierarchical inconsistencies.[6]

3.10. Alternative Comparison Matrix.

After forming a comparison matrix of wood products based on criteria, the priority weight comparison matrix for each criterion is sought.

- Alternative comparison matrices based on Physical Properties of Wood(SFK)

Table 11. Alternative comparison matrix tables based on the criteria of Wood Physical Properties.

\begin{tabular}{|l|c|c|c|c|c|}
\hline SFK & KJ & KT & KM & KA & Weight \\
\hline KJ & 1,00 & 2,00 & 4,00 & 3,00 & $\mathbf{0 , 4 5}$ \\
\hline KT & 0,50 & 1,00 & 2,00 & 3,00 & $\mathbf{0 , 2 8}$ \\
\hline KM & 0,25 & 0,50 & 1,00 & 0,33 & $\mathbf{0 , 1 0}$ \\
\hline KA & 0,33 & 0,33 & 3,00 & 1,00 & $\mathbf{0 , 1 7}$ \\
\hline Total & $\mathbf{2 , 0 8}$ & $\mathbf{3 , 8 3}$ & $\mathbf{1 0 , 0 0}$ & $\mathbf{7 , 3 3}$ & $\mathbf{1 , 0 0}$ \\
\hline
\end{tabular}

- Alternative comparison matrices based on Wood Mechanical Properties(SMK)

Table 12. Alternative comparison matrix tables based on the criteria of Wood Mechanical Properties.

\begin{tabular}{|l|c|c|c|c|c|}
\hline \multicolumn{1}{|c|}{ SMK } & KJ & KT & KM & KA & Weight \\
\hline KJ & 1,00 & 3,00 & 4,00 & 1,00 & $\mathbf{0 , 3 9}$ \\
\hline KT & 0,33 & 1,00 & 2,00 & 5,00 & $\mathbf{0 , 3 1}$ \\
\hline KM & 0,25 & 0,50 & 1,00 & 0,33 & $\mathbf{0 , 0 9}$ \\
\hline KA & 1,00 & 0,20 & 3,00 & 1,00 & $\mathbf{0 , 2 1}$ \\
\hline Total & $\mathbf{2 , 5 8}$ & $\mathbf{4 , 7 0}$ & $\mathbf{1 0 , 0 0}$ & $\mathbf{7 , 3 3}$ & $\mathbf{1 , 0 0}$ \\
\hline
\end{tabular}

- Alternative comparison matrices based on Wood Class(KK)

Table 13. Alternative comparison matrix tables based on Wood Class criteria.

\begin{tabular}{|l|c|c|c|c|c|}
\hline \multicolumn{1}{|c|}{ KK } & KJ & KT & KM & KA & Weight \\
\hline KJ & 1,00 & 2,00 & 3,00 & 4,00 & $\mathbf{0 , 4 4}$ \\
\hline KT & 0,50 & 1,00 & 2,00 & 5,00 & $\mathbf{0 , 3 0}$ \\
\hline KM & 0,33 & 0,50 & 1,00 & 0,33 & $\mathbf{0 , 1 1}$ \\
\hline KA & 0,25 & 0,20 & 3,00 & 1,00 & $\mathbf{0 , 1 5}$ \\
\hline Total & $\mathbf{2 , 0 8 3}$ & $\mathbf{3 , 7 0}$ & $\mathbf{9 , 0 0}$ & $\mathbf{1 0 , 3 3}$ & $\mathbf{1 , 0 0}$ \\
\hline
\end{tabular}


- Alternative comparison matrices based on Wood Age(UK)

Table 14. Alternative comparison matrix tables based on Wood Age criteria.

\begin{tabular}{|l|c|c|c|c|c|}
\hline UK & KJ & KT & KM & KA & Weight \\
\hline KJ & 1,00 & 2,00 & 3,00 & 2,00 & $\mathbf{0 , 4 0}$ \\
\hline KT & 0,50 & 1,00 & 4,00 & 2,00 & $\mathbf{0 , 3 1}$ \\
\hline KM & 0,33 & 0,25 & 1,00 & 0,33 & $\mathbf{0 , 0 9}$ \\
\hline KA & 0,50 & 0,50 & 3,00 & 1,00 & $\mathbf{0 , 2 0}$ \\
\hline Total & $\mathbf{2 , 3 3}$ & $\mathbf{3 , 7 5}$ & $\mathbf{1 1 , 0 0}$ & $\mathbf{5 , 3 3}$ & $\mathbf{1 , 0 0}$ \\
\hline
\end{tabular}

- Alternative comparison matrices based on Wood Substances(ZK)

Table 15. Alternative comparison matrix tables based on Wood Material criteria.

\begin{tabular}{|l|c|c|c|c|c|}
\hline \multicolumn{1}{|c|}{ ZK } & KJ & KT & KM & KA & Weight \\
\hline KJ & 1,00 & 2,00 & 0,50 & 1,00 & $\mathbf{0 , 2 5}$ \\
\hline KT & 0,50 & 1,00 & 1,00 & 0,50 & $\mathbf{0 , 1 7}$ \\
\hline KM & 2,00 & 1,00 & 1,00 & 0,50 & $\mathbf{0 , 2 5}$ \\
\hline KA & 1,00 & 2,00 & 2,00 & 1,00 & $\mathbf{0 , 3 3}$ \\
\hline Total & $\mathbf{4 , 5 0}$ & $\mathbf{6 , 0 0}$ & $\mathbf{4 , 5 0}$ & $\mathbf{3 , 0 0}$ & $\mathbf{1 , 0 0}$ \\
\hline
\end{tabular}

3.11. Eigen Criteria and Alternatives (Final Results).

After finding the weights of each criterion, the final step is to multiply the weights of each criterion with the weights of each type of wood. Then the multiplication results are added in rows, so that the total global priorities are obtained as shown in table 16.

Table 16. Table of criteria and alternative eigenvalues.

\begin{tabular}{|c|c|c|c|c|c|c|c|}
\hline \multirow{2}{*}{ Weight } & SFK & SMK & KK & UK & ZK & \multirow{2}{*}{ Value } & \multirow{2}{*}{ Rank } \\
\cline { 2 - 6 } & 0,27 & 0,10 & 0,36 & 0,14 & 0,13 & & \\
\hline KJ & 0,45 & 0,39 & 0,44 & 0,40 & 0,25 & $\mathbf{0 , 4 7}$ & $\mathbf{1}$ \\
\hline KT & 0,28 & 0,31 & 0,30 & 0,31 & 0,17 & $\mathbf{0 , 2 8}$ & $\mathbf{2}$ \\
\hline KM & 0,10 & 0,09 & 0,11 & 0,09 & 0,25 & $\mathbf{0 , 1 2}$ & $\mathbf{4}$ \\
\hline KA & 0,17 & 0,21 & 0,15 & 0,20 & 0,33 & $\mathbf{0 , 1 9}$ & $\mathbf{3}$ \\
\hline
\end{tabular}

Conclusions from teak wood alternatives were ranked first as a result of decisions with the highest quality wood.
1. Teak Wood $(\mathrm{KJ})$
(first rank)
2. Trembesi wood (KT) (second rank)
3. Acacia wood (KA) (third place)
4. Mahogany $(\mathrm{KM}) \quad$ (fourth place)

\section{Conclusions}

4.1. The criteria that influence the determination of wood quality in Jati Muria Source are the criteria for the Physical Properties of Wood with a value of $0.272(27 \%)$, then the Mechanical Properties of the Wood 0.095 (10\%), Wood Grade 0.361 (36\%), Wood Age 0.137 (14\%), Wood substance $0.134(13 \%)$

4.2. From the AHP matrix analysis, the decision model with priority is obtained, for all the weights / priority criteria and alternatives that are the best priority for wood used for furniture. $28(28 \%)$, rank 3 Acacia wood with a value of $0.19(19 \%)$, rank 4 Mahogany with a value of $0.12(12 \%)$.

4.3. AHP method turns out to be used in determining the quality of wood, because the method is able to solve the multi-criteria problem that has not been structured into structured and easier to understand with accurate results.

4.4. The decision support system model for determining wood material using the AHP method has 5 criteria, namely, Physical Properties of Wood, Mechanical Properties of Wood, Wood Class, Age of Wood and Wood Substance, while alternatives consist: Teak Wood, Trembesi Wood, Mahogany, Acacia Wood. 


\section{Reference}

[1] S. Hanggana, Prinsip Dasar Akuntansi Biaya. surakarta: mediatama, 2006.

[2] J. D. C. Little, "Models and managers: The concept of a decision calculus," Management Science. 2004, doi: $10.1287 / \mathrm{mnsc} .1040 .0267$.

[3] T. L. Saaty, "What is the Analytic Hierarchy Process?," in Mathematical Models for Decision Support, 1988.

[4] I. H. Al Amin, "Sistem Pendukung Keputusan dengan Metode Analitychal Hierarchy Process (AHP) untuk Pemilihan Strategi Proses Produksi yang Efisien” Dinamika Teknik, Vol. 2 No 1. 2008.

[5] Bourgeois, R., "Analytical Hierarchy Process: an Overview" UNCAPSA - UNESCAP. Bogor, 2005.

[6] S. N. Anwar and R. B. N. Prameswari, "Sistem Pendukung Keputusan Pemilihan Distributor dengan Metode Analytical Hierarchy Process (AHP) Berbasis Web Mobile” vol. 9, p. 1, 2019.

JURNAL ILMIAH KOMPUTERISASI AKUNTANSI Vol. 13, No. 1, Juli $2020: 37-46$ 